FILOZOFIA

Roč. 75,2020 , č. 4

DOI: https://doi.org/10.31577/filozofia.2020.75.4.4

\title{
OTVORENÁ TEXTÚRA POJMOV A PRAVIDIEL - VODA NA MLYN PRE SUBJEKTIVIZMUS V APLIKOVANEJ SÉMANTIKE?
}

FRANTIŠEK GAHÉR, Filozofický ústav Slovenskej akadémie vied, Bratislava, SR

MICHAL MRVA, Katedra teória práva a sociálnych vied, Právnická fakulta Univerzity Komenského v Bratislave, Bratislava, SR

MAREK ŠTEVČEK, Katedra občianskeho práva, Právnická fakulta Univerzity Komenského v Bratislave, Bratislava, SR

MARTIN TURČAN, Katedra teória práva a sociálnych vied, Právnická fakulta Univerzity Komenského v Bratislave, Bratislava, SR

GAHÉR, F., MRVA, M., ŠTEVČEK, M., TURČAN, M.: Open Texture of Concepts and Rules - Fuel for the Fire of Subjectivism in Applied Semantics?

FILOZOFIA, 75, 2020, No 4, pp. $309-323$

\begin{abstract}
When using natural language in a domain of a special discipline, which is fundamentally based on its use (for example, language of law), we are led on the one hand by the need for precision and unambiguity and on the other hand by the need for brevity and efficiency. A specific semantic problem for texts expressing a system of normative rules for the regulation of actions is the question of their efficient applicability in new situations. Herbert Hart came up with a suggestion on how to solve these dilemmas in the field of law and was loosely inspired by the theory of open texture of concepts. He saw the solution in an inevitable defeasibility of a rule, which, in his view, is caused by the open texture of the goal pursued by the rule. However, extensive use of the instrument of open texture of a concept or a rule can be fuel for the fire of subjectivism in semantic practice. It is necessary to distinguish the phenomenon of open texture of concepts from the polysemy of natural language expressions and the phenomenon of so-called privative modification. Applicative flexibility and effectiveness of normative theory is aided by a more appropriate generality of concepts, which is achieved, for example, by recodification of law, rather than by artificially extending the scope of concepts on the basis of their fuzziness.
\end{abstract}

Keywords: Open texture of a concept / rule - Semantics - Generality - Fuzziness Polysemy - Privative modification

\section{0. Úskalia aplikovanej sémantiky}

Akokol'vek precízne vybudovaná sémantická teória musí svoju opodstatnenost' dokázat' $\mathrm{v}$ aplikačnej praxi. Teória zvyčajne vychádza z idealizácie, ale pri svojom uplatnení používa opačný proces konkretizácie. $\mathrm{V}$ procese konkretizácie sémantickej teórie môžeme 
vidiet' nutné zmierňovanie idealizácie, východiskových kritérií a princípov. Opodstatnenost' ústupkov z požiadaviek na presnost') pri praktickej aplikácii sa zvykne zdôvodňovat' rozmanitost'ou situácií a okolností použitia jazyka. Niekedy sa však môže javit' ako prístup lenivého sémantika, ktorý si úlohu privel'mi zl'ahčuje a vyhovára sa na neodstránitel'nú neostrost' použitých pojmov, zažratú neurčitost' významov slovných spojení a celých viet či textov. Pokúsime sa o „vyvážený“ pohl’ad na limity aplikácie sémantickej teórie medzi teoretickou požiadavkou na presnost' a pragmatickou požiadavkou na efektívnost', pričom gravitačným centrom explikácie bude otvorená textúra pojmu, respektíve pravidla. Oblast'ou aplikácie bude najmä právo - niektoré teoretické i praktické otázky.

\section{Presnost' verzus stručnost' verzus nejednoznačnost' textu}

Pre výlučne informatívne typy textov, kde sa takmer vôbec nevyskytujú emocionálne zafarbené slová, metafory a podobné jazykové prostriedky, je žiaduca ich presnost' a vysoký stupeň informačnej jednoznačnosti a zrozumitel'nosti. Za také môžeme považovat' technické opisy, návody na použitie, lekárske správy, ale aj sústavy predpisov vrátane zákonov a pod.

$\mathrm{Na}$ druhej strane princíp ekonómie vyjadrovania aj $\mathrm{v}$ takýchto textoch vedie $\mathrm{k}$ ich zhutňovaniu $-\mathrm{k}$ ich čo najstručnejšiemu vyjadreniu. Keby sme napríklad v zložitom predpise viackrát opakovali tie isté slovné spojenia, mohol by pôsobit' t’ažkopádne. Požiadavka presnosti, jednoznačnosti, je akoby v nepriamom pomere k požiadavke stručnosti: čím je text presnejší, jednoznačnejší, tým je rozsiahlejší, a naopak, čím je text stručnejší, koncíznejší, tým väčšia nejednoznačnost' hrozí. ${ }^{1}$

Jednoznačnost' takýchto textov je znižovaná významovou nejednoznačnost'ou použitých výrazov i nejednoznačnou formuláciou ich vzájomného spojenia, a v neposlednom rade neurčitost'ou či „,nedourčenost'ou“ (underspecification) celkového významu z hl'adiska jeho jednoznačnej aplikability v praxi. Recepcia zložitých textov závisí od kompetentnosti adresáta a niektoré spôsoby spojenia slov preňho môžu byt' t'ažšie pochopitel'né, alebo dokonca klamlivé. Ku klamlivým označeniam sa ešte vrátime, avšak všeobecný problém nedourčenosti textov prekračuje zámer tohto článku.

Použité výrazy jazyka môžu byt' významovo nejednoznačné najmä pre svoju neostrost' alebo viacznačnost' (homonymiu, polysémiu). V sémantických teóriách, ktoré explikujú významy výrazov prirodzeného jazyka ako určité procedúry, metódy identifikácie, ${ }^{2}$ je známe, že základné empirické pojmy, významy výrazov vzt’ahujú-

\footnotetext{
${ }^{1}$ Bližšie o tom Gahér, Števček, Braxatoris (2019).

${ }^{2}$ Duží, Jespersen, Materna (2010).
} 
cich sa na oblast' časopriestorových objektov, nie sú algoritmizovatel'nými procedúrami. Povedané inými slovami, nevieme ich modelovat' ako mechanické metódy identifikácie, ktoré by efektívne rozhodli v každej možnej situácii. Takéto pojmy môžeme spresňovat', nahrádzat' presnejšími, ale dokonalú presnost' nedosiahneme. Ak je presnost' použitých pojmov v pragmatických situáciách dostatočná a nerozhodnuté prípady sa nevyskytujú vôbec, alebo len vel'mi výnimočne, niet dôvodu ich nahrádzat' ostrejšími pojmami, respektíve menit' základné pojmy konceptuálnych sústav. Ak nerozhodnutých prípadov je nadkritické množstvo, pričom svojimi dôsledkami spôsobujú vážnejšie aplikačné problémy, tak je to podnet na redefinovanie pojmov, prípadne na zmenu celej konceptuálnej sústavy.

Špecifickým sémantickým problémom v prípade textov vyjadrujúcich systém nejakých normatívnych pravidiel na regulovanie konania (napríklad etických noriem, právnych predpisov) je otázka ich efektívnej aplikovatelnosti v nových situáciách. Požiadavka takejto aplikačnej pružnosti v jazyku vyjadrených pravidiel je priamo úmerná ich všeobecnosti, ktorú môžeme dosahovat' najmä dostatočnou všeobecnost'ou základných pojmov. Ak však vo formuláciách pravidiel použijeme príliš všeobecné pojmy, tak môžeme znížit' ich aplikačnú jednoznačnost' a predvídatel'nost'.

S návrhom na riešenie tejto dilemy pre oblast' práva prišiel svojho času Herbert Hart a inšpiroval sa teóriou otvorenej textúry pojmu, ktorú rozpracoval jeho oxfordský kolega Fridrich Waismann (Gahér 2018). Je zrejmé, že Hart sa nedržal tohto prameňa presne a môžeme diskutovat' o tom, ako to vlastne myslel.

\section{Otvorená textúra pravidla a jeho aktuálna neostrost’?}

Hart v diele Pojem práva, v časti VII. Formalizmus a skepticizmus voči pravidlám, uvádza príklad s pojmom vozidla (vehicle) $(1961 / 2004,133)$ a nadväzuje na známu diskusiu s Lonom Fullerom o vzt’ahu práva a morálky $(1958,610) .{ }^{3}$ Hart sa pýta, ako máme v prípade zákazu vozidiel v parku rozhodnút' o detskom autíčku poháňanom elektrinou? Hart je presvedčený, že s touto eventualitou sme (ako zákonodarcovia) pri formulovaní zákazu nepočítali a určite sú možné aj iné situácie, s ktorými sme počitat' nemohli.

Hart v prípade aplikácie pravidla navrhuje rozlíšit tie konkrétne situácie, v ktorých rozhodujeme s istotou (jadro istoty, angl. a core of certainty), a iné situácie, kde vznikajú pri aplikovaní pravidla pochybnosti (polotieň pochybností, angl. penumbra of doubt). Podl'a Harta „všetky pravidlá teda majú akýsi lem neurčitosti či, otvorenú textúru““(1961/2004, 127).

\footnotetext{
${ }^{3}$ Hart zaujímal pozitivistickú pozíciu, podl’a ktorej právo a morálka nemajú spoločný presah, na druhej strane Fuller bol zástanca tézy, že morálka je v práve prítomná.
} 
Zdá sa, že pojem otvorená textúra mal argumentom Harta v diskusii s Fullerom a ostatnými odporcami pozitivizmu v teórii práva pridat' novú silu. Pripomeňme, že Fuller v predchádzajúcej diskusii o aplikácii zákazu vozidiel v parku $(1958,663)$ namietal, že takýto zákaz by sa nemal vzt'ahovat' napríklad na výnimočnú situáciu, ked' by veteráni vojny v parku chceli umiestnit' funkčné vojnové vozidlo ako pamätník. To sa nedá zdôvodnit' otvorenou textúrou pojmu vozidlo, pretože ide o prípad, ktorý patrí do jadra istoty významu výrazu vozidlo.

Pripomeňme si, že Waismann pripúšt’al možnost', že hoci mnohé empirické pojmy sú z hl'adiska aktuálneho poznania presne definované a jednoznačné, predsa budú potenciálne neostré. Preto by mohol odmietnut' hovorit' o otvorenej textúre pojmu vozidla ako o jeho aktuálnej neostrosti, a povedal by, že pri dostatočnom úsilí by sme pre aktuálne známe prípady dopravných prostriedkov vedeli pojem vozidla definovat' dostatočne ostro. Otvorená textúra pojmu vozidlo by sa týkala budúcich nových a nepredvídaných situácií, čiže išlo by len o jeho potenciálnu (intenzionálnu) neostrost'.

\section{Otvorená textúra ciel’a, ktoré pravidlo sleduje, vedie neodvratne $\mathrm{k}$ jeho revízii?} Hart sa však od Waismannovej teórie otvorenej textúry pojmu zrejme odklonil programovo. Brian Bix už dávnejšie upozornil, že Hart chápe výraz otvorená textúra značne odlišne od Waismanna (Bix 1991, 51 a n.), a to zrejme nie preto, aby nutnost' právneho uváženia zdôvodnil jednoducho povahou jazyka, ale preto, aby zdôvodnil, prečo si aplikácia pravidiel pre celú triedu prípadov vyžaduje práve takéto uváženie, diškréciu. Otvorená textúra u Harta sa netýka len vymedzenia všeobecných pojmov, ktoré sú zložkami pravidla, ale aj ciel'ov, ktoré pravidlo sleduje (Hart 2010,133). Uvažuje, že určitú úroveň pokoja v parku ako ciel’ zákazu pohybu vozidiel by sme mohli obetovat' v prospech detí, aby mohli používat' elektricky poháňané autíčka, alebo naopak, pokoj v parku pred týmito autíčkami ochránit'.

Do hry takto vstupuje ako zásadný faktor ciel', účel zákazu, a ten môže byt' $v$ určitom napätí, nie $\mathrm{v}$ úplnej zhode, alebo dokonca $\mathrm{v}$ určitom rozpore $\mathrm{s}$ formuláciou vlastného pravidla, zákazu. Pravidlo by sa dalo revidovat' dodaním výnimky: pokial nejde o vozidlo na účely pamätníka. Samozrejme, výnimiek uvádzaných spojením pokial' nie (ibaže, unless) môže byt' vel’a. Otázkou je, či ich všetky vieme vyčerpávajúco sformulovat', alebo či vždy zostanú niektoré výnimky nesformulované a môžu otvárat' potrebu revízie pravidla, respektíve zdôvodňovat' jeho neaplikovanie, hoci explicitná podmienka pre aplikovanie je splnená. Dôvodom na výnimky z pravidla je otvorená textúra ciel'a, ktorý pravidlo sleduje (Hart), alebo jednoducho to, že skutočný zmysel pravidla sa pri jeho aplikáciách postupne odhaluje, ale nikdy nie úplne (Fuller). Pri- 
rodzene, že dôvodom pre neaplikovanie takéhoto pravidla je účinnost' nejakého silnejšieho pravidla. To však nie je zdôvodnené otvorenou textúrou pravidla, ale nanajvýš otvorenou textúrou jeho explicitného ciel'a.

Frederick Schauer $(2011,1)$ si myslí, že Hart vlastne chcel zdôvodnit' tézu, že aktuálne pravidlá je zbytočné spresňovat', pretože bol presvedčený, že sa nedajú spresnit' zásadne a pri ich aplikácii vždy bude dochádzat' $\mathrm{k}$ ich opodstatnenému porušovaniu či neaplikovaniu aj v situáciách, ked’ podmienky pre aplikáciu sú zjavne splnené (teda $\mathrm{k}$ revidovaniu, angl. necessary defea sibility of legal rules). Inými slovami povedané, revidovanie právnych pravidiel a potreba uváženia pri ich aplikácii sú podl'a Harta neodvratné. Mohli by sme povedat', že Hart zastáva tézu neodvratnosti revidovania právnych pravidiel ako stavu, ktorý je špecifický pre právo a vlastne normálny. Schauer proti tomu namieta $(2011,23)$, že otvorená textúra pravidiel je záležitost' jazyka (vlastne sémantická záležitost'), a nie je špecifická pre právo alebo niektorú jeho oblast'. Ak sa týka pravidiel v práve, tak preto, že sú formulované v jazyku, a nie preto, že sa týkajú práva.

Schauer konštatuje, že „kl'účovou ideou revidovatel'nosti (defeasibility) (...) je možnost' pre toho, kto aplikuje, interpretuje alebo vynucuje pravidlo, urobit' ad hoc alebo podnietit' pre tento okamih prispôsobenie, aby vylúčil nie optimálny, neefektívny, nečestný, nespravodlivý alebo inak neakceptovatel’ný výsledok stanovený pravidlom“ (Schauer 2012, 81). Podl'a Schauera „revidovatel'nost' nie je vlastnost'ou pravidiel vôbec, ale skôr charakteristikou toho, ako niektoré systémy rozhodovania zaobchádzajú so svojimi pravidlami“ (Schauer 2012,87).

\section{Otvorená textúra pojmu a polysémia}

Za dobrú ilustráciu otvorenej textúry jazyka práva dnes niektorí autori označujú pojem (biologickej) matky. Jan Broulík (Broulík 2014) a Ondřej Málek (Málek 2016, 89) uvádzajú, že tento pojem je výstižným príkladom potenciálnej neurčitosti. Zatial' čo tradične bola za biologickú matku považovaná výlučne žena, ktorá diet’a porodila a v duchu zásady mater semper certa est ani nikomu nenapadlo, že v budúcnosti by bolo možné považovat' za matku aj nejakú inú osobu, podl'a súčasných úvah by to mohla byt' nielen (1) žena, ktorá diet’a vynosí a porodí, ale aj darkyňa vajíčka - a to (2) darkyňa jadra vajíčka i (3) darkyňa vajička bez jadra. To, na čo pri pojme matky kedysi nikto nepomyslel, je aktuálne možné. Ktorá $\mathrm{z}$ uvedených osôb by teda mala byt' $\mathrm{v}$ prípade účasti viacerých žien na privedení nového jedinca na svet považovaná za jeho „matku“ s rodičovskými právami a povinnost'ami: (3) darkyňa jadra vajíčka, (2) darkyňa vajíčka bez jadra, alebo (1) žena, ktorá oplodnené vajíčko „len“ vynosí? 
Keby sa do zákona o rodine presadila napríklad definícia pojmu matky ako darkyne jadra vajíčka, tak by v sporných situáciách nastala potreba uskutočňovania verifikácie procesu oplodnenia (tvorby vajíčka) alebo následných genetických testov, rovnako ako je to pri spochybnení otcovstva zo strany manžela, druha a pod. Jeden pojem matky v starej konceptuálnej sústave by sa rozštiepil na tri nové pojmy, pričom jeden z nových pojmov by s ním bol totožný. Podkladom utvorenia dvoch nových pojmov, ich proliferácie, bol pôvodne zamlčaný vedecký či odborný (substančný) pojem (Gahér 2018, 627 a n.). Mohli by sme dokonca hovorit' o novej explikácii tohto pojmu, ktorý bol v pozadí pôvodného explicitného pojmu, pretože tento substančný pojem je oným spojivom pôvodného príznakového pojmu a dvoch nových príznakových (fenomenologických) pojmov (Gahér 2018, 627, pozn. 25).

Nie je to však na základe intervencie otvorenej textúry pojmu či otvoreného textu pôvodnej definície pojmu (ako substančného pojmu), ani jeho neostrosti - ten z hl'adiska verifikovatel'nosti zostal nezmenený a rovnako jednoznačný - jeho neostrost' nebola nijako tematizovaná ani spochybnená. Otázkou sa akurát stalo, ktorý z týchto pojmov najlepšie vystihuje intuíciu predteoretického substančného pojmu matky. Z hladiska pomeru ovplyvnenia dedičnosti diet'at'a je v súčasnosti jednoznačným kandidátom darkyňa jadra vajička, pretože darkyňa vajička bez jadra sa údajne podiel'a na celkovej dedičnosti diet'at'a len asi desatinou percenta. Rozhodnutie by malo byt', samozrejme, konzultované s odborníkmi z oblasti genetiky. Nech už by bolo akékol'vek, vo výsledku by sa nemalo stat', že by ,[n]arodené diet'a potom bolo súčasne potomkom aj súrodencom ženy, od ktorej pochádza oplodnené vajíčko, ale vlastne tiež diet’at’om a vnukom svojej rodičky“" (Vostal, 2001).

Vzhl'adom na obsahovú blízkost' pôvodného pojmu a nástupníckych pojmov sa teda síce môže zdat', že stále ide o jeden pojem, ktorý sa upravuje, koriguje, nie je to však tak. Jeden odborný (substančný) pojem je jednoducho nahradený inými odbornými pojmami, čo znamená, že ide o polysémiu, a nie o otvorenú textúru.

V súvislosti s problémom polysémie $\mathrm{v}$ práve možno ako dobrý aktuálny príklad $\mathrm{v}$ krátkosti zmienit’ aj pojem rodu. Jeden z ústavných článkov garantuje základné práva a slobody bez ohl'adu na ,... pohlavie, rasu, farbu pleti (...) majetok, rod alebo iné postavenie." Je nepochybné, že pod rodom sa tu mal na mysli pôvod. Ide teda o rod v zmysle prostredia, z ktorého človek pochádza (napr. rolnícky, sedliacky, robotnícky $\operatorname{rod}^{4}$ a pod.). $V$ duchu niektorých súčasných iniciatív však možno uvažovat' aj o genderovom rode (teda o mužskom, ženskom či inom). ${ }^{5}$ Je zrejmé, že pri takomto narábaní s výrazom rod máme do činenia s polysémiou - $\mathrm{s}$ homonymami. Je predsa roz-

\footnotetext{
${ }^{4}$ https://slovnik.juls.savba.sk/?w=rod, navštívené dňa 24. 2. 2020.

${ }^{5}$ Takáto iniciatíva čítania predmetného ústavného článku sa už u nás údajne objavila.
} 
diel, ked' hovoríme o rode ako o pôvode človeka, a ked' hovoríme o rode ako o psychosexuálnej identite človeka. Pri úsilí interpretovat' predmetné ustanovenie tak, že rod $\mathrm{v}$ ňom znamená genderový rod, pravdaže nepôjde o posun vo význame jedného a toho istého pojmu, teda o to, že by sa v priebehu času zmenil význam výrazu rod ako pôvodu pridaním alebo odobratím nejakého znaku (ako sa to na prvý pohl'ad môže zdat' pri pojme biologickej matky; hoci, ako sme videli, ani tam to tak v skutočnosti nie je). Pôjde o to, že pojem rod má (alebo aspoň môže mat') viacero úplne odlišných významov, ktoré nemajú prakticky žiadne spoločné znaky; sú homonymami. ${ }^{6}$

\section{Otvorená textúra pojmu - nutná mnohoznačnost' textu?}

Niektorí teoretici práva tvrdia, že ,[o]tvorená textúra práva predstavuje pravdepodobne najdôležitejšiu koncepciu vysvetl'ujúcu nevyhnutnú mnohoznačnost' práva (právneho textu),“respektíve, že ,[o]tvorená textúra práva patrí k predpokladom fungovania európskeho ústavného pluralizmu, lebo ulahčuje vyhýbanie sa konfliktom ústavných systémov a obmedzuje tie, ktoré vzniknú" (Bárány 2016, 9). ${ }^{7}$ Toto stanovisko sa môže javit' ako prístup „lenivého“ sémantika, ktorý si úlohu príliš zl'ahčuje a údajnú „nevyhnutnú mnohoznačnost' právneho textu“ predkladá ako jeho prednost'.

Vysvetlenie, že „[p]rávne princípy majú nadpriemerne otvorenú textúru, čiže umožňujú v rôznych kontextoch nerovnaké interpretácie,“ (Bárány 2016, 12) by mohlo byt' pochopené tak, že je v rozpore s princípom de similibus idem est iudicandum (podobné veci majú byt' súdené rovnako, respektíve podobne). ${ }^{8} \mathrm{Na}$ druhej strane ono vysvetlenie môže byt' nahradené zrozumitelnejším i presvedčivejším vysvetlením bez odkazu na zaklínadlo otvorenej textúry: právne princípy sú ex definitione všeobecné a výsledok ich aplikácie závisí od okolností konkrétneho prípadu prinajmenej tak, ako hodnota funkcie závisí od vstupnej hodnoty argumentu funkcie (veličiny, nezávislej premennej).

\footnotetext{
${ }^{6}$ Správna interpretácia ústavného textu si, samozrejme, musí byt' tejto pomerne triviálnej skutočnosti vedomá, inak dôjde $\mathrm{k}$ výkladu založenému na polysémickom klame. Pozri Mrva, M., Turčan, M.: Interpretácia a argumentácia v práve. Bratislava: Wolters Kluwer 2016, 54).

${ }^{7}$ Bárány, E. (2016): Otvorená textúra práva v ústavnom pluralizme. In: Otvorená textúra ústavy. Trnavská univerzita v Trnave, Trnava.

${ }^{8}$ Najvyšší súd Slovenskej republiky vo svojom uznesení (3 Cdo 158/2012) uviedol: „Takýto stav, ked' rozhodnutia súdov, vrátane najvyššieho súdu, posudzujúce tú istú právnu otázku sú zásadne odlišné, je v priamom rozpore s požiadavkou právnej istoty, ktorej imanentnou súčastou je právo účastníka, aby rozhodnutia súdov boli predvídatel’né a aby účastníci konania mohli mat' dôveru v to, že rovnaké veci budú rovnakým spôsobom súdené. Záver o tom, že rozporná a vzájomne si protirečiaca judikatúra súdov je porušením práv účastníka konania, vyplýva z rozhodnutia Európskeho súdu pre l’udské práva vo veci Beian proti Rumunsku zo dňa 5. decembra 2007.“
} 
Odkaz na otvorenú textúru ako na zdravú črtu právneho textu nájdeme aj vo vel'mi vecných vyjadreniach renomovaných autorov. Napríklad Karel Eliáš v súvislosti s novým českým Občianskym zákonníkom uvádza: „Stará moudrost praví, že zákon má být prostředně jasný. Půjde-li do př́lišných podrobností ,tvrdými‘ ustanoveními, nastaví bariéry sociálnímu a ekonomickému vývoji, ustrne-li na holé abstrakci, dá motivaci k voluntaristickému a nepředvídatelnému zasahování do soukromých záležitostí (vzpomeňme, jak odkaz starého zákonníku v $§ 2$ odst. 3 na ,povahu ustanovení ‘ jako kritérium kogentnosti umožnil omezování autonomie vůle prohlašováním kdejakého ustanovení zákona za donucující). Nový zákoník usiluje jít střední cestou, snaží se vyhnout záhadným formulacím i kazuistickým pravidlům, staví na generálních klauzulích a adresuje svoji důvěru soudci. Proto je zákoník vystavěn jako otevřená textura - na soudci bude, aby pro konkrétní př́ípad zvážil, zda tu je mimořádný zájem ( $\$ 98)$, spravedlivý důvod (§ 220, 1244), mimořádná okolnost (§ 755) nebo událost (§ 1542), aby posoudil, zda jde o zjevnou svévoli (§ 1551), mimořádný př́ípad (§ 1659), hrubý nepoměr (§ 1299, 1765, 1793, 1796), hrubý rozpor s obchodními zvyklostmi (§ 1801) nebo zjevnou či hrubou nespravedlnost (§ 1162, 1963) apod.“ (Eliáš, 2013).

Domnievame sa, že Eliášovi ide o „strednú určitost“" pojmov - myšlienka, že slová zákona majú byt' „prostredne jasné“, je alúziou na aforizmus Emanuela Tilscha, vel'kého civilistu prelomu 19. a 20. storočia, ktorý takto obhajoval existenciu nie celkom „,jednoznačných“ pojmov v rakúskom Všeobecnom občianskom zákonníku. Ide o symptomatickú a dobre opísanú tradíciu hl'adania úlohy sudcu v stredoeurópskom právnom priestore, ovplyvnenom germánskou tradíciou takzvaného dotvárania práva súdom (Fortbildung des Recht). Predovšetkým v prácach Viktora Knappa (Knapp 1993, 725 a n.) a Eliáša (2013) sa české právne prostredie snaží definovat' samo seba ako prostredie s právnym jazykom „tilschovskej“ sémantiky semi-pružnosti výrazov právneho jazyka. Nejde však o otvorenú textúru, ale o aktuálnu neurčitost' pojmov.

\section{Otvorená textúra pojmu a nevlastná modifikácia}

Schauer si v článku o otvorenej textúre práva kládol otázku, či nealkoholické (správnejšie odalkoholizované) víno je víno $(2011,4)$ a ako tento problém súvisí s otvorenou textúrou pojmu. Tu však podl'a nás vstupuje do hry ako rozhodujúci faktor skôr otázka povahy modifikácie ako otázka potenciálnej či intenzionálnej neostrosti pojmu.

Intenzionálnu teóriu modifikácie rozpracoval Richard Montague (1970a). Podla tejto teórie významom adjektívnej frázy je funkcia z vlastností do vlastnosti (Montague 1974, 211). Ked' sa zameriame väčšmi na významovú ako na syntaktickú stránku, môžeme povedat', že významom adjektíva je funkcia, ktorá prirad’uje vý- 
znamu podstatného mena význam mennej frázy, teda napríklad význam výrazu bystrý je funkcia, ktorá priradí významu výrazu človek význam spojenia bystrý človek. Takéto predikatívne použitie adjektív je vysvetl'ované pomocou výpustky ako eliptické atributívne použitie. Čiže propozícia Tento človek je bystrý je analyzovaná ako Tento človek je bystrý človek.

Na Montagueho teóriu vlastnej predikácie nadviazal Hans Kamp (1975) a rozlíšil tie adjektíva (prídavné mená), ktoré reprezentujú len vlastnosti (vystupujú len v predikatívnej pozícii), d’alej adjektíva, ktoré reprezentujú len modifikátory vlastností (vystupujú len v atributívnej pozícii), a napokon pripustil také adjektíva, ktoré môžu vystupovat' aj v predikatívnej aj v atributívnej pozícii. Takéto rozlíšenie umožňovalo vysvetlit' chybné úsudky, ktoré už dávnejšie predložil Peter Geach (1956, 33): Ak a je vel'ká mucha, tak a je mucha a a je vel'ká; ak b je malý slon, tak b je slon a $\boldsymbol{b}$ je malý; [ked’že $\boldsymbol{a}$ a $\boldsymbol{b}$ sú živočichy], tak $\boldsymbol{a}$ je velký živočich a $\boldsymbol{b}$ je malý živočich. Chybnost' úsudku spočivala v tom, že adjektívum vel'ký bolo zaradené do skupiny adjektív, ktoré môžu vystupovat' aj v predikatívnej aj v atributívnej pozícii. Za také sa však považujú adjektíva tvaru (okrúhly), farby (žltý, červený), ktoré môžu plnit' aj úlohu vlastnosti aj úlohu modifikátora vlastností. V takomto prípade sa hovorí o prienikovej (intersektívnej) modifikácii (Duží 2010, 37 a n.; Duží, Materna 2012, 4. kap., Duží 2017, 601 a n.). Napríklad ak $\boldsymbol{a}$ je okrúhly kolik, tak $\boldsymbol{a}$ je okrúhly a $\boldsymbol{a}$ je kolik. Ak $\boldsymbol{b}$ je červené víno, tak $\boldsymbol{b}$ je červené a $\boldsymbol{b}$ je víno. Úloha takýchto absolútnych prídavných mien nezávisí od významu predikátu, ktorý modifikujú (sú predikatívne simpliciter), ich extenzia nezávisí od podstatného mena, s ktorým sa kombinujú (Kamp 1974, 124). Kamp ako príklady uvádza technické a vedecké výrazy endokrinný, supravodivý. Diskusia, či vôbec existujú takéto absolútne empirické vlastnosti aj $\mathrm{v}$ bežnej slovnej zásobe a či vlastne nejde o rýdzo podradzujúcu (subsective) vlastnú modifikáciu, je otvorená (Jespersen 2016, 536). ${ }^{9}$

Rýdzo podradzujúca (subsective) vlastná modifikácia je utváraná skalárnymi adjektívami ako napríklad malý, vel'ký, šikovný, bystrý a pod. (Duží, Fait 2017, 38). Úloha týchto adjektív závisí od významu predikátu, ktorý modifikujú, pričom platí pravidlo odvodenia podradenia sprava (right subsectivity) (Jespersen 2016, 533): Ak je Peter zručný huslista, tak Peter je huslista. Ak je tento Peter aj gitarista, tak nemusí byt' aj zručný gitarista. Tá zručnost' sa pozitívne „pridala“ $\mathrm{k}$ Petrovej vlastnosti huslistu, nie priamo k Petrovi v absolútnom zmysle, a formulácia Peter je aj zručný je akceptovaná ako odvoditel'ná len $\mathrm{v}$ tom zmysle, že je vypustený predmet predikácie (huslista), vzhl'adom na čo je Peter zručný. Peter nie je zručný absolútne, teda vo

\footnotetext{
${ }^{9}$ Proti ich existencii svedčí prípustnost' neskrátenej, ale významovo rovnocennej formulácie: výrok a je okrúhly sa významovo nelíši od neelidovaného výroku Tvar a je okrúhly, resp. výrok $\boldsymbol{b}$ je červené sa významovo nelíši od výroku Farba b je červená.
} 
vzt’ahu ku všetkým vlastnostiam. Inými slovami, najprv vyberieme množinu huslistov, potom ich vlastnú podmnožinu zručných. Prídavné meno zručný nevyčleňuje v absolútnom zmysle nejakú množinu zručných objektov.

Kamp okrem vlastných adjektív (predicative) explikoval aj nevlastné, zbavujúce (privatívne - privative) adjektíva (Kamp 1974, 125). Ide vlastne o operáciu, ktorou získame negovanú vlastnost' po aplikácii na určitú vlastnost'. Predikovaním vlastnosti falošná na vlastnost' bankovka získame vlastnost' falošná bankovka, ktorá sa už nebude vzt'ahovat' na žiadne (skutočné) bankovky. Ak $\boldsymbol{c}$ je falošná bankovka, tak z toho nevyplýva, že $\boldsymbol{c}$ je falošná a $\boldsymbol{c}$ je bankovka.

Vlastnost' je privatívna vo vzt'ahu k určitej vlastnosti, ale nemusí byt' privatívna k niektorej inej vlastnosti. Drevený je vlastný modifikátor k predikátu stôl, lyžička, lavica, strecha a pod., ale nevlastný, privatívny modifikátor k vlastnostiam mačka, človek, kôn. Vlastnost' mŕtvy je privatívny modifikátor k vlastnosti človek, ale nie je privatívny (zbavujúci) $\mathrm{k}$ vlastnosti kameň.

Maketa tanku nie je tank, ale predsa je významovo bližšia k tanku ako kameň, pretože medzi tankom a jeho maketou je podobnost'. Špeciálnu skupinu privatívnych modifikátorov tvoria tie, ktoré sú aplikované na vlastnost', ktorú indivíduum najprv $\mathrm{v}$ určitom časovom úseku malo a potom ju stratilo. ${ }^{10}$ Takými sú adjektíva bývalý (bývalý minister vlády), predchádzajúci (predchádzajúci riaditel'). V prípade l’adovca je to napríklad adjektívum roztopený. Aj v tomto prípade je medzi pôvodnou vlastnostou indivídua a vlastnostou indivídua, ktorá je výsledkom aplikácie modifikátora na túto vlastnost', určitá významová blízkost'. Tak to je aj s prípadom odalkoholizovaného vína: je to produkt, ktorý vznikol úpravou vína tak, že ho zbavil základného atribútu pojmu vína (rekvizity z esencie pojmu, pojmového znaku) - alkoholu. Už to nie je žiadny druh vína, pretože nemá nutný atribút, ktorý je v definícii pojmu vína uvedený: víno je alkoholický nápoj, ktorý sa vyrába alkoholovým kvasením vylisovanej št’avy z plodov viniča hroznorodého. Čiže nemáme dva druhy vína - alkoholické a odalkoholizované, hoci v spojení odalkoholizované víno je použitý názov víno. Čiže ak je pravda, že $\boldsymbol{d}$ je odalkoholizované víno, tak nie je pravda, že $\boldsymbol{d}$ je víno.

Podobne nemáme dva druhy bankoviek - pravé a falošné - hoci falošné bankovky sa podobajú na bankovky a mohli vzniknút úpravou bankoviek (dopísaním núl do znaku pre ich nominálnu hodnotu). S návrhom, že v niektorých použitiach adjektívum falošný neplní úlohu privatívneho modifikátora, prišla Barbara Partee $(2001,1)$ - hovorila o modifikácii s donútením, ked’že považovala za zmysluplné skúmat', či ide

${ }^{10}$ Bližšie o tom Jespersen, Carrara, Duží $(2017,50)$. 
o pravú alebo falošnú bankovku. Proti tomuto návrhu argumentovali Duží a spol. (2010, 400, pozn. 52; Jespersen, Carrara, Duží 2017, 51).

Špeciálnu skupinu tvoria takzvané modálne modifikátory ako napríklad slovo údajný, ktoré sa riadia osobitými pravidlami. Ak je niekto údajný vrah, tak sa v budúcnosti vlastnost' byt' vrahom, na ktorú je modifikátor údajný aplikovaná, môže potvrdit', ale aj vyvrátit'.

Teória adjektívnych modifikátorov pri vlastnej modifikácii predpokladá, že podstatné meno, ku ktorému sa modifikujúce adjektívum viaže, reprezentuje vlastnost' nefalšovane a použitý modifikátor nie je vzhl'adom $\mathrm{k}$ tejto vlastnosti zjavne privatívny (zbavujúci). Tento predpoklad pri niektorých označeniach pomocou adjektívnych fráz nemusí byt' splnený a takéto označenia môžeme hodnotit' ako klamlivé. Príkladom takéhoto označenia je spojenie nátierkové (česky pomazánkové) maslo. Hoci toto údajné maslo vyzerá ako maslo a plní podobné úlohy pri príprave potravín ako maslo, predsa však (pravým) maslom nie je, pretože nie je vyrobené tak, že plní parametre masla (atribúty, rekvizity, esencie masla) ako potraviny s definovaným zložením tukov (živočíšneho, nie rastlinného pôvodu), sušiny a vody v stanovených hodnotách (pojem maslo). A práve preto Súdny dvor EÚ svojím rozhodnutím ${ }^{11}$ určil, že ,[m]liečny výrobok, ktorý nemožno považovat' za maslo [nesplńa definíciu masla ako výrobku], nemôže byt' predávaný pod obchodným označením ,pomazánkové máslo (nátierkové maslo) ‘."

Takže otvorená textúra pojmu nesúvisí s privatívnou modifikáciou.

\section{7. Čo pomáha aplikačnej pružnosti viac - neostrost' či všeobecnost' pojmov?}

Pružnost' pri aplikácii napríklad nejakej sústavy pravidiel konania na nové situácie je niekedy hodnotená ako cennejšia vlastnost' ako aplikačná nedefinovanost', hoci pre staré prípady bol systém pravidiel jednoznačný: je lepšie, ak sústava pravidiel dáva v starých situáciách menej jednoznačnú odpoved' a v nových tiež nejakú, hoci menej určitú, ako v starých jednoznačnú a v nových žiadnu. Niektorí autori sa domnievajú, že rozširovat' rozsah aplikability pravidiel bez ich menšej či radikálnejšej úpravy (revízie, novelizácie) môžeme na základe neostrosti pojmov, ktorú pokladajú napríklad v súvislosti s otvorenou textúrou pojmov takpovediac za zákonitú súčast' „života“ pojmov (Bárány 2016, 12). Podl’a niektorých autorov dokonca aktuálnej neostrosti pojmov v oblasti právnych pojmov je dost' a nemusíme sa vôbec zaoberat' potenciálnou neostrost'ou (Endicot 2003, 38).

Aplikačnú pružnost' regulatívnych pravidiel však ovel’a lepšie zabezpečuje primeraná miera všeobecnosti t’ažiskových pojmov. Ak táto miera všeobecnosti nie je dostatočná, tak nat'ahovanie rozsahu (extenzie) pojmov z titulu ich neostrosti pôsobí

${ }^{11}$ Rozhodnutie SD EÚ č. C-37/11. 
násilne, nepresvedčivo a koniec-koncov neefektívne. Nafukovaním neostrosti nejakého pojmu o čosi rozšírime jeho rozsah, extenziu, ale nedospejeme $\mathrm{k}$ jeho dostatočnému zovšeobecneniu. Hoci teleologické metódy interpretácie etických, právnych a iných noriem nám umožňujú vo výnimočných situáciách prekročit' v danej situácii úzky rámec explicitného rozsahu aplikability predpisu a vyhnút' sa vynútenej novelizácii, predsa si to vyžaduje dodatočnú intelektuálnu prácu toho, kto rozhoduje o aplikácii, pričom môže byt' poznačená jeho subjektivizmom či partikulárnym záujmom.

Ak takýchto výnimiek je nadkritické množstvo alebo majú zásadnú povahu, čo vždy treba posúdit' jednotlivo pre každé pravidlo, tak napokon je primeranejšie nahradit' pôvodný pojem všeobecnejším prostredníctvom novelizácie pravidla.

Dobrým príkladom takéhoto príbehu je nahradenie pojmov dom a byt pojmom obydlie v otázke trestného činu porušovania domovej slobody. Starý Trestný zákon definoval túto skutkovú podstatu ako neoprávnené vniknutie do domu alebo bytu iného. V jednom prípade vznikla otázka, či aj neoprávnené vniknutie do hotelovej izby patrí pod túto skutkovú podstatu. Keby pojem dom-byt bol definovaný ako stavba určená na bývanie, tak by sa táto charakteristika dala v nejakej miere prisúdit’ aj hotelovej izbe. Výsledkom bolo kontroverzné rozhodnutie, ${ }^{12}$ ktorým súd na základe predmetného ustanovenia odsúdil aj neoprávnené vniknutie do hotelovej izby. V odôvodnení súd argumentoval, že objektom trestného činu je nedotknutel'nost' bývania konkrétnej osoby, a preto nie je rozdiel medzi domom určeným na trvalé bývanie a objektom určeným na prechodné ubytovanie, akým je rekreačná chata alebo hotelová izba. Toto rozhodnutie však bolo kontroverzné, pretože trestné právo bolo vždy založené na zásade nullum crimen sine lege a použitie analógie, hoci aj na základe teleologickej úvahy, v neprospech páchatel’a sa považovalo za vylúčené. Problém odstránila rekodifikácia trestného práva $\mathrm{v}$ roku 2005, ktorá s účinnost'ou od 1. januára 2006 definuje skutkovú podstatu trestného činu porušovania domovej slobody ako vniknutie do obydlia iného. Pojem dom-byt a jeho rozšírenie o hotelovú izbu bolo nahradené všeobecnejším pojmom obydlie.

Vo vzt'ahu k aplikačnej pružnosti v práve a s tým súvisiacim problémom neostrosti či všeobecnosti pojmov je azda vhodné dat' do pozornosti aj problematiku dualizmu práva na verejné a súkromné. $Z$ princípov tohto delenia vyplýva, že právne normy verejného práva by mali byt' formulované čo najexaktnejšie a najkonkrétnejšie, ked’že orgány verejnej moci môžu autoritatívne zasahovat' do práv a slobôd fyzických a právnických osôb. $Z$ tohto dôvodu môžu konat' len v právom predvídaných a dovolených prípadoch. Súkromné právo je zas ovládané dispozičnou autonómiou, ktorá

${ }^{12}$ Rozhodnutie NS ČSR č. R 8/1990. 
vychádza zo zásady, že v súkromnoprávnych vzt’ahoch môžu účastníci robit' všetko, čo nie je zákonom zakázané. Preto postihnút' všetky možné druhy konania subjektov v rámci súkromnoprávnych vzt'ahov je jednak prakticky nemožné, a jednak aj neúčelné. Práve preto je vhodné a účelné, ak v odvetviach súkromného práva normotvorca použije a používa pojmy, ktoré sú do určitej miery abstraktné, dostatočne všeobecné, avšak samozrejme za predpokladu, že použitie takéhoto pojmu je vhodné.

Pokial' ide o verejné právo, používanie neurčitých pojmov by malo byt' eliminované, ked’že predstavujú potenciálne riziko zneužitia verejnej moci. Verejné právo má byt', a aj musí byt', podstatne viac kazuistické ako právo súkromné. Inak by pre orgány verejnej moci existoval priestor na potenciálne zneužitie.

V rovine súkromného práva je vel’a príkladov na použitie nie dostatočne určitých či až neurčitých pojmov. Možno spomenút' napríklad ustanovenie Občianskeho zákonníka, podl'a ktorého právny úkon je neplatný, ak je v rozpore s dobrými mravmi ${ }^{13}$ alebo iné ustanovenie toho istého právneho predpisu, podl'a ktorého má fyzická osoba právo domáhat' sa najmä, aby sa upustilo od neoprávnených zásahov do práva na ochranu jej osobnosti, aby sa odstránili následky týchto zásahov a aby jej bolo dané primerané zadost'učinenie ${ }^{14}$ a pod.

\section{Záver}

Pokúsili sme sa zdôvodnit', že pri používaní výrazov odborného jazyka, ktorý v zásadnej miere vychádza z prirodzeného jazyka (takýmto odborným jazykom je napríklad jazyk práva), sme navádzaní protikladnými tendenciami: na jednej strane úsilím o presnost' a jednoznačnost', a na druhej strane snahou o stručnost' a efektívnost'. Zaoberali sme sa návrhom ako riešit' túto dilemu pre oblast' práva v nových situáciách, s ktorou svojho času prišiel Herbert Hart. Hart sa vol’ne inšpiroval teóriou otvorenej textúry ројти Fridricha Waismanna a prišiel k záverom o neodvratnej revidovatel'nosti pravidiel. Dôvodom pre výnimky z pravidla je podla neho otvorená textúra ciel’a, ktorý pravidlo sleduje. Demonštrovali sme, že nevhodné či neprimerané používanie inštrumentu otvorenej textúry pojmu či pravidla môže byt' vodou na mlyn pre subjektivizmus v sémantickej praxi. Vysvetlili sme, prečo od fenoménu otvorenej textúry pojmu treba odlišovat' polysémiu výrazov i jav takzvanej nevlastnej modifikácie. Na záver sme zdôvodnili tézu, že aplikačnej pružnosti a efektívnosti normatívnej teórie väčšmi ako umelé rozširovanie rozsahu pojmov na základe ich neostrosti $-\mathrm{v}$ princípe neodstránitel'nej - pomáha primeraná všeobecnost' pojmov, ktorá sa dosahuje napríklad rekodifikáciou zákona.

${ }^{13} \S 39$ zákona č. 40/1964 Zb. Občianskeho zákonníka v znení neskorších predpisov.

14 § 13 ods. 1 zákona č. 40/1964 Zb. Občianskeho zákonníka v znení neskorších predpisov. 


\section{Literatúra}

BÁRÁNY, E. a kol. (2016): Otvorená textúra práva v ústavnom pluralizme. In: Dekan, T., Šeliga, J.: Otvorená textúra ústavy. Trnavská univerzita v Trnave, Trnava.

BIX, B. (1991): H. L. A. Hart and the "Open Texture" of Language. Law and Philosophy, 1991, 10, 51- 72. DOI: https://doi.org/10.1007/BF00144295.

BROULÍK, J. (2014): „Otevřená textura“ v právu, Jiné právo. Dostupné na: http://jinepravo. blogspot.com/2014/10/otevrena-textura-v-pravu.html (Navštívené: 8. 11. 2019).

ELIÁŠ, K. (2013): Jak je to s pravidly výkladu, analogií a úlohou soudce. Právní rádce, 28. 1. 2013. Dostupné na: http://obcanskyzakonik.justice.cz/index.php/home/infocentrum/media/ 512-jak-je-to-spravidly-vykladu-analogii-a-ulohou-soudce (Navštívené: 14. 2. 2020).

ENDICOTT, T. (2000): Vagueness in Law (reprinted 2003). Oxford: University Press.

DUŽÍ, M., JESPERSEN, B., MATERNA, P. (2010): Procedural Semantics for Hyperintensional Logic: Foundations and Applications of Transparent Intensional Logic, Dordrecht: Springer.

DUŽÍ, M., MATERNA, P. (2012): TIL jako procedurálni logika. Bratislava: Aleph.

DUŽÍ, M. (2017): Property Modifiers and Intensional Essentialism. Computación y Sistemas, 21 (4), 601 - 613. DOI: http://dx.doi.org/10.13053/cys-21-4-2811.

DUŽÍ, M., FAIT, M. (2017): Property Modifiers. Dostupné: https://nlp.fi.muni.cz/raslan/ 2017/paper04-Duzi_Fait.pdf (Navštívené 20. 10. 2019).

FULLER, L. (1958): Positivism and Fidelity to Law: A Reply to Professor Hart. Harvard Law Review, 71 (4), $630-672$.

GAHÉR, F. (2018): Otvorená textúra pojmu - pôvodný zmysel a kritika. Filozofia, 73 (8), 620 635.

GAHÉR, F., ŠTEVČEK, M., BRAXATORIS, M. (2019): Nástroje a pravidlá produkcie a interpretácie koncízneho textu (s osobitným zretel'om na normativitu). Jazykovedný časopis, 70 (1), 75 - 94. DOI: https://doi.org/10.2478/jazcas-2019-0041.

GEACH, P. T. (1956): Good and Evil. Analysis, 17, 33 - 42. DOI: https://doi.org/10.1093/ analys/17.2.33.

HART, H. L. A. (1958): Positivism and the Separation of Law and Morals. Harvard Law Review, $71(4), 593-629$.

HART, H. L. A. (2010): Pojem práva. Český Těšín: Prostor.

JESPERSEN, B., CARRARA, M., DUŽÍ, M. (2017): Iterated privation and positive predication. The Journal of Applied Logic, 25, Supplement, 48 - 71. DOI: https://doi.org/ 10.1016/ j.jal.2017.12.004.

JESPERSEN, B. (2016): Left subsectivity: how to infer that a round peg is round. Dialectica, 70 (4), 531 - 547. DOI: https://doi.org/10.1111/1746-8361.12159.

KAMP, H. (1975): Two Theories about Adjectives. In: Keenan, E. L. (ed.): Formal Semantics of Natural Language. Cambridge: Cambridge University Press, 123 - 155.

KNAPP, V. (1993): Př́nos středoevropského soudnictví k evropské právní kultuře. Právník, 132 (9), $725-736$

MÁLEK, O. (2016): Neurčité použití pojmů ve Waismannově pojetí. In: Dekan, T, Šeliga, J.: Otvorená textúra Ústavy. Trnava: Trnavská univerzita, 85 - 91.

MONTAGUE, R. (1970a): English as a formal language. In: B. Visentini, et al. (eds.): Linguaggi nella Società e nella Tecnica. Milan: Edizioni di Communita, 189-224; Reprinted in Thomasson, R. H. (ed.) (1974): Formal Philosophy. New Haven - London: Yale University Press.

MRVA, M., TURČAN, M. (2016): Interpretácia a argumentácia v práve. Bratislava: Wolters Kluwer.

PARTEE, B. (2001): Privative Adjectives: Subsective Plus Coercion. In: Bäuerle, R., Reyle, U., Zimmermann, T. E. (eds.): Presuppositions and Discourse. Amsterdam: Elsevier. 
RODRIGUEZ, J. L. (2012): Against Defeasibility of Legal Rules. In: Beltran, J.F., Ratti, G., B. (eds.): The Logic of Legal Requirements. Essays on Defeasibility. Oxford: Oxford University. DOI: https://doi.org/10.1163/9789004253162_011.

SLOVENSKÉ SLOVNÍKY [online], https://slovnik.juls.savba.sk/?w=rod (Navštívené 24. 2. 2020).

SCHAUER, F. (2011): On The Open Texture Of Law. Dostupné na: http://legacydirs.umiacs. umd.edu/ horty/courses/readings/schauer-2011-open-texture.pdf (Navštívené 24. 2. 2020).

SCHAUER, F. (2012): Is Defeasibility an Essential Property of Law? In: Beltran, J. F. - Ratti, G., B. (eds.): The Logic of Legal Requirements. Essays on Defeasibility. Oxford: Oxford University, $77-88$.

VOSTAL, Z. (2001): Sporná môže byt' už aj matka. Korzár, 27. 4. 2001.

Článok bol podporený projektom č. APVV-18-0417 Historický vývoj terminológie súkromného práva na Slovensku pre potreby rekodifikácie slovenského občianskeho práva

František Gahér

Filozofický ústav SAV

Klemensova 1

81364 Bratislava 1

Slovenská republika

e-mail: frantisek.gaher@uniba.sk

ORCID ID: https://orcid.org/0000-0001-6892-1429

Marek Števček

Katedra občianskeho práva

Právnická fakulta UK v Bratislave

Šafárikovo námestie 6

P. O. BOX 313

81000 Bratislava

Slovenská republika

e-mail:marek.stevcek@uniba.sk

ORCID ID: https://orcid.org/0000-0002-8154-2375
Michal Mrva

Katedra teória práva a sociálnych vied

Právnická fakulta UK v Bratislave

Šafárikovo námestie 6, P. O. BOX 313

81000 Bratislava, Slovenská republika

e-mail: michal.mrva@flaw.uniba.sk

ORCID ID: https://orcid.org/0000-0002-0741-5538

Martin Turčan

Katedra teória práva a sociálnych vied

Právnická fakulta UK v Bratislave

Šafárikovo námestie 6

P. O. BOX 313

81000 Bratislava

Slovenská republika

e-mail: martin.turcan@flaw.uniba.sk

ORCID ID: https://orcid.org/0000-0002-4616-6730 